\title{
Penyuluhan Menyikapi Kondisi Pandemi Corona dengan Hidup Sehat dan Makan Makanan Bergizi
}

\author{
Feti Fatonah ${ }^{1}$, Suse Lamtiar ${ }^{2}$, Dian Anggraini P ${ }^{3}$, Lia Retno $W^{4}$, Ai Dewi Kosmala ${ }^{5}$ \\ 1,2,3,4,5 Politeknik Penerbangan Indonesia Curug \\ e-mail: 1 feti_fatonah@yahoo.co.id, ${ }^{2}$ suce64@gmail.com, ${ }^{3}$ dian.anggraini@ppicurug.ac.id, \\ ${ }^{4}$ lia.retnoningrum@gmail.com, ${ }^{5}$ ai_dkosmala7582@yahoo.co.id
}

\begin{abstract}
Abstrak
Sebagian orang beranggapan bahwa pandemi Corona yang saat ini menjadi wabah di seluruh dunia, membuat orang menjadi putus asa dan bahkan terpikir untuk bunuh diri. Kondisi ini diperparah dengan banyaknya PHK dari perusahaan. Sebagian ibu rumah tangga merasa berputus asa dalam menyikapi pandemi ini, mereka berpikir tentang Bagaimana mensiasati kondisi agar badan tetap fit, dengan menjaga kesehatan keluarga ditengah pandemi ini, serta mengatur pola makan gizi seimbang dengan keuangan yang minim. Tentu hal ini bukanlah hal mudah bagi sebagian ibu rumah tangga. Kenapa yang dipilih ibu rumah tangga? Karena pengelola keuangan, pengatur pola makanan pada saat kondisi pandemi adalah ibu rumah tangga. Dalam menyikapi pandemi ini Politeknik Penerbangan Indonesia ikut berperan serta mengurangi dampak pandemi, salah satunya melalui kegiatan penyuluhan, yang dilaksanakan oleh Dosen dalam kegiatan Pengabdian Masyarakat kepada ibu ibu rumah tangga Anggota Dharma Wanita PPIC yang ada di sekitar kampus Politeknik Penerbangan Indonesia, yaitu di desa serdang wetan, kecamatan legok, kabupaten Tangerang. Kegiatan PKM ini merupakan suatu media yang menghubungkan dunia pendidikan dengan Masyarakat sekitar. Kegiatan PKM ini dilaksanakan dengan memberikan penyuluhan kepada ibu ibu di sekitar kampus PPIC, diharapkan kegiatan ini akan menambah wawasan pada para Ibu rumah tangga bahwa kondisi pandemi saat ini tidak dapat dihadapi hanya dengan panik, tetapi harus dengan ilmu dan wawasan untuk menyiasati menu makanan yang bervariasi dan gizi seimbang dengan tidak perlu mahal, serta mengajak anggota keluarga untuk selalu menerapkan hidup sehat, agar imun tubuh meningkat, sehingga terhindar dari virus Corona
\end{abstract}

Kata Kunci : Gizi Seimbang, Hidup sehat, Pandemi Corona

\begin{abstract}
Currently a plague all over the word makes people feel hopeless and even think about suicide. This condition is exacerbated by the many layoffs from companies. Some housewives feel hopeless in responding to this pandemic, they think about how to deal with conditions to keep the body fit, with maintain family health amidst this pandemic as well as regulate a balanced nutritional diet wth minimal finances. Of course this is not easy for some housewives. Why do housewives choose? Because the financial manager who regulates food patterns during pandemic conditions is a housewife. In responding to the pandemic, the Indonesian Avition Polytechnic has participated in reducing the impact of the pandemic, one of which is through counseling activities, which are carried out by lecturers in community service activities to housewives, Dharma Wanita members the PPIC around the Indonesian Polytechnic campus, namely in serdang wetan village, Legok sub-district, Tangerang district. This PKM activity is a medium that connects the word of education with the surrounding community, this PKM activity is carried out by providing counseling to mothers around the PPIC campus, it is hoped that this activity will add insight to housewives that the current pandemic conditions cannot be faced only by panic but it must be with the knowledge and insight to get around a varied diet and balanced nutrition without being expensive, and invite family members to always live a healthy life, so that the body's immunity increases, so that you can avoid the corona virus.
\end{abstract}

Keywords : Balanced Nutrition, Healthy life, The corona pandemic 


\section{Pendahuluan}

Banyak orang beranggapan bahwa pandemi Corona yang saat ini menjadi wabah di seluruh dunia, membuat orang menjadi putus asa dan bahkan terpikir untuk bunuh diri. Kondisi ini diperparah dengan banyaknya PHK dari perusahaan. Sebagian ibu rumah tangga merasa berputus asa dalam menyikapi pandemi ini, mereka berpikir tentang Bagaimana mensiasati kondisi agar badan tetap fit, dengan menjaga kesehatan keluarga ditengah pandemi ini, serta mengatur pola makan gizi seimbang dengan keuangan yang minim. Tentu hal ini bukanlah hal mudah bagi sebagian ibu rumah tangga. Kenapa yang dipilih ibu rumah tangga? Karena pengelola keuangan, pengatur pola makanan pada saat kondisi pandemi, dengan slogan " di rumah aja " adalah ibu rumah tangga.

Menurut Peraturan Pemerintah No. 4 tahun 2014 tentang Penyelenggaraan Pendidikan Tinggi dan Pengelolaan Perguruan Tinggi, Pengabdian Masyarakat merupakan suatu media yang menghubungkan dunia pendidikan dengan Masyarakat sekitar, dalam hal ini Politeknik Penerbangan Indonesia Curug, guna memberikan manfaat kepada Masyarakat sekitar. PPIC merupakan Politeknik penerbangan yang berada di Kec. Legok Kab Tangerang, dalam hal kegiatan pengabdian masyarakat perlu untuk ikut ambil bagian dalam program mencerdaskan anak bangsa yang berada di sekitar kampus, hal ini selain sebagai bentuk Tridharma Perguruan Tinggi juga sebagai wujud nyata kepedulian PPIC dalam meningkatkan SDM

Perlu kiranya dalam menyikapi pandemi ini Politeknik Penerbangan Indonesia ikut berperan serta mengurangi dampak pandemi , salah satunya melalui kegiatan penyuluhan, yang dilaksanakan oleh Dosen dalam kegiatan Pengabdian Masyarakat kepada ibu ibu rumah tangga yang ada di sekitar kampus Politeknik Penerbangan Indonesia, yaitu di desa serdang wetan, kecamatan legok, kabupaten Tngerang. Kegiatan PKM ini merupakan suatu media yang menghubungkan dunia pendidikan dengan Masyarakat sekitar. Kegiatan PKM ini dilaksanakan dengan memberikan penyuluhan kepada ibu ibu anggota Dharma Wanita PPIC yang ada di sekitar kampus PPIC. Kegiatan ini dilaksanakan bekerjasama dengan Dharmawanita PPIC, mencakup ibu ibu rumah tangga pensiunan PPIC, maupun ibu ibu rumah tangga anggota dharmawanita PPIC yang masih aktif dan ibu ibu anggota kegiatan Posyandu Dharmawanita PPIC. Dengan adanya kegiatan PKM ini merupakan bukti nyata peran serta PPIC dalam mengurangi dampak pandemi Covid 19 dan diharapkan dapat memberikan solusi bagi ibu rumah tangga, serta dapat menambah wawasan bagi para ibu rumah tangga dalam menyikapi pandemi ini, yaitu dengan keuangan minim , tetap menyiapkan makanan gizi seimbang agar menjadikan keluarga tetap sehat.

\section{Metode}

Metode yang dipakai adalah berbentuk Penyuluhan, dengan mempertimbangkan latar belakang peserta yaitu adalah ibu-ibu rumah tangga di sekitar kampus PPIC yang juga anggota Dharmawanita PPIC, pelaksanaan kegiatan dibuat menyenangkan dengan diajarkan cara hidup sehat di masa pandemi corona, dan cara mengelola makanan sesuai gizi seimbang di masa pandemi..

\section{Hasil dan Pembahasan}

Hasil dari kegiatan penyuluhan ini adalah para peserta Ibu- ibu anggota Dharmawanita PPIC memahami cara hidup sehat dan cara mengelola makanan dengan gizi seimbang di masa pandemi corona.

Pembahasan Materi meliputi : 
1. Sosialisasi hidup sehat di era new normal

a. Adaptasi Kebiasaan Baru, yaitu menerapkan pola hidup sehat dengan wajib pakai masker, jaga jarak, sering cuci tangan pakai sabun, bawa hand sanitizer, jika bertemu tidak bersalaman dll

b. Menerapkan etika batuk dan bersin. Yaitu dengan cara menutup mulut dan hidung menggunakan lengan atas bagian dalam ataupun bisa menggunakan kain tisu untuk menutup hidung dan mulut saat batuk dan bersin dan selepasnya langsung dibuang.

c. Cek suhu tubuh saat akan masuk ruang public. Suhu normal adalah dibawah 37,2'C.

d. Menjaga kesehatan dan selalu melaksanakan olah raga

Pola hidup sehat yang juga tidak boleh terlewatkan adalah berolahraga, di masa pandemi ini olahraga bisa juga dilaksanakan di dalam rumah.

e. Jika kontak dengan ODP ataupun PDP

Melaksanakan Isolasi Mandiri, ini dilakukan jika kita merasa tidak sehat, memiliki gejala penyakit seperti : demam, batuk, pilek, nyeri tenggorokan atau sesak nafas.

2. Mengatur pola makanan bergizi seimbang di era pandemi covid 19

a. Gizi seimbang merupakan

susunan pangan sehari-hari yang mengandung zat gizi dalam jenis dan jumlah yang sesuai dengan kebutuhan tubuh, dengan memperhatikan prinsip :

- keanekaragaman pangan,

- aktivitas fisik,

- perilaku hidup bersih dan

- memantau berat badan secara teratur dalam rangka mempertahankan berat badan normal untuk mencegah masalah gizi

b. Prinsip gizi seimbang

- Mengkonsumsi makanan yang beraneka ragam

- Pentingnya pola hidup aktif dan berolahraga

- Menerapkan pola hidup bersih dan sehat

- Menjaga berat badan ideal

c. Gizi seimbang untuk meningkatkan sistem imun, harus mengandung :

- Vit A, terlibat dalam pembentukan, produksi, dan pertumbuhan sel darah merah, sel limfosit, antibodi juga integritas sel epitel pelapis tubuh

- Vit C, meningkatkan sistem imun, melindungi tubuh dari zat kimia berbahaya dan polusi udara

- Vit D, dapat menjadi alternatif sebagai suplemen pada pencegahan penyakit pernapasan

- Vit E, sebagai antioksidan yang mampu mempertahankan integritas membran sel.

- Zat besi ( Fe), Berperan dalam imunitas dan pembentukan sel-sel limfosit serta dapat mencegah terjadinya infeksi

- Zinc, Berperan untuk sintesa protein. Protein merupakan komponen terbesar dalam pembentukan antibody

- Selenium, selenium bekerjasama dengan vitamin E dan berperan sebagai antioksidan

d. Makanan yang mengandung Zat yang dibutuhkan tubuh Antara lain : 


\begin{tabular}{|l|l|}
\hline \multicolumn{1}{|c|}{ ZAT GIZI } & \multicolumn{1}{c|}{ BAHAN MAKANAN } \\
\hline Protein & Daging Sapi, Ayam, Telur, Ikan, Udang, Cumi-cumi, Tiram, Susu Full Cream \\
\hline Vitamin A & $\begin{array}{l}\text { Minyak Ikan, Sayuran berwarna merah, orange : Wortel, Tomat, Bayam } \\
\text { Merah, Ubi Jalar, Paprika, Kentang, Labu, Labu Kuning, Kol, Jagung Aprikot, } \\
\text { Blewah, Jeruk, Mangga dan Semangka }\end{array}$ \\
\hline Vitamin C & Jambu Biji, Kiwi, Pepaya, Jeruk, Tomat, Brokoli, Stawberry \\
\hline Vitamin D & Ikan Laut (Ikan Salmon, Tongkol, Tuna, Kakap, Makarel), Susu, Telur \\
\hline Seng/Zinc (Zn) & Susu Full Cream, Kacang Merah, Ayam, Kacang Hijau, Tempe, Udang \\
\hline Selenium (Se) & Daging Sapi, Telur, Ikan Salmon, Ayam, Susu dan hasil olahanya, Sereal \\
\hline Zat Besi (Fe) & Daging Sapi, Ayam, Udang, Sayuran berdaun hijau \\
\hline Probiotik & Yoghurt \\
\hline
\end{tabular}

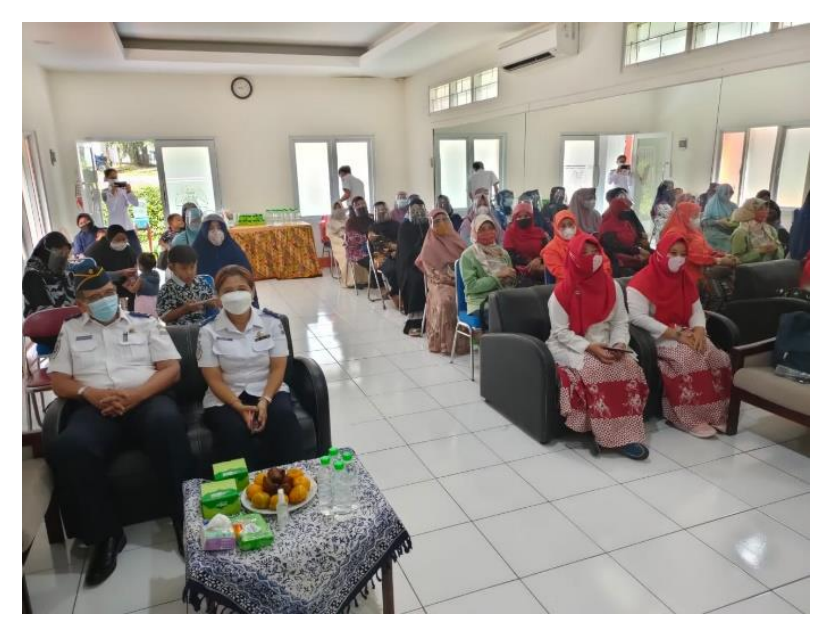

Gambar1, pelaksanaan kegiatan

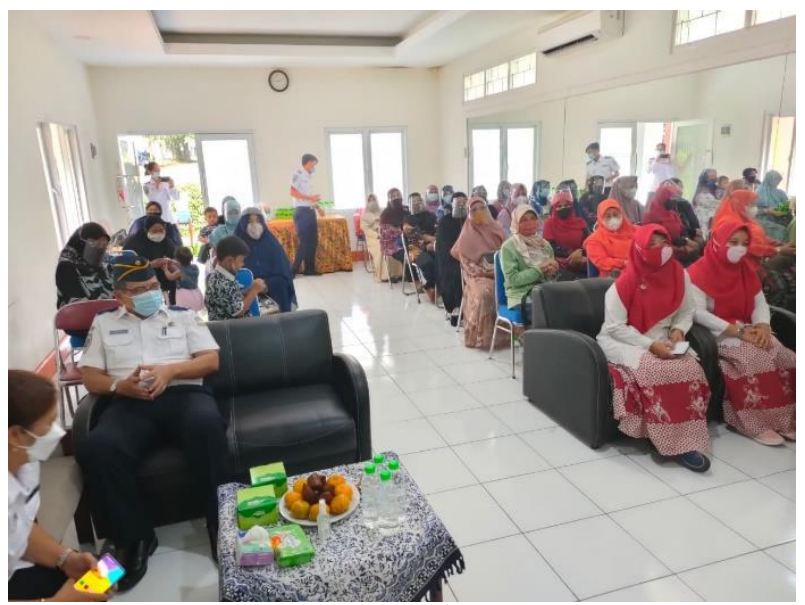

Gambar 2, Pelaksanaan kegiatan 


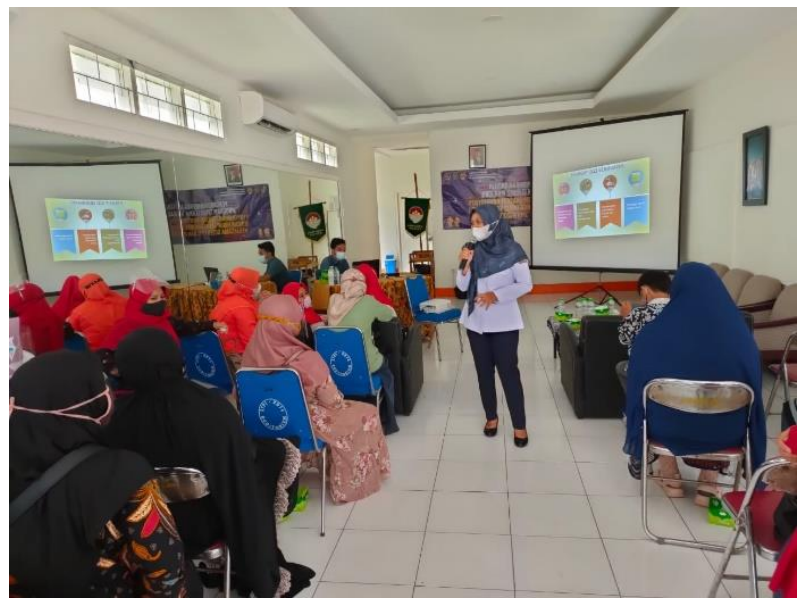

Gambar 3, pelaksanaan Sosialisasi

\section{Kesimpulan}

Bahwa Kegiatan PKM, dengan tema sosialisasi tentang menerapkan hidup sehat dan makan makanan bergizi di era pandemi ini sangat bermanfaat, terlihat saat para peserta secara antusias bertanya tentang bagaimana hidup sehat dan menu yang baik di era covid 19. Dengan adanya pengabdian masyarakat ini, diharapkan tidak ada kepanikan di masyarakat, saat terserang covid 19, dan agar para peserta dapat selalu berpikir positif dalam menghadapi rutinitas di era pendemi covid ini. Tujuan dari kegiatan pengabdian masyarakat ini adalah bahwa Politeknik Penerbangan Indonesia ikut berperan serta mengurangi dampak pandemi covid 19, salah satunya melalui kegiatan penyuluhan, yang dilaksanakan oleh Dosen dalam kegiatan Pengabdian Masyarakat kepada ibu ibu yang ada di sekitar kampus Politeknik Penerbangan Indonesia, yaitu di desa serdang wetan, kecamatan legok, kabupaten Tangerang. Dengan adanya kegiatan PKM ini merupakan bukti nyata peran serta PPIC dalam mengurangi dampak pandemi Covid 19 dan diharapkan dapat memberikan solusi bagi ibu rumah tangga , serta dapat menambah wawasan bagi para ibu rumah tangga dalam menyikapi pandemi ini, yaitu dengan keuangan minim, tetap menyiapkan makanan gizi seimbang agar menjadikan keluarga tetap sehat.

\section{Daftar Pustaka}

Departemen Kesehatan RI 2010, Perilaku hidup bersih dan sehat di rumah tangga, Jakarta, Depkes RI, 2010.

Ema Hanifah 2011, “Cara Hidup Sehat”. Sarana Bangun Pustaka, Jakarta 2011

Esi Emilia 2009. "Pengetahuan,Sikap, dan Praktek Gizi pada Remaja dan Implikasinya pada Sosialisasi Perilaku Hidup Sehat' “Jurnal Media, Pendidikan, Gizi dan Kuliner” UPI vol. 1 No. 12009

https://www.unicef.org/indonesia/id/coronavirus/tips-menyiapkan-makanan-yang praktisekonomis-dan-sehat-pada-masa-pandemi-covid-19, Tips menyiapkan makanan yang praktis ekonomis dan sehat pada masa pandemi covid 19, Unicef 2020.

https://covid19.go.id, Kementerian Kesehatan RI 2020, Panduan Gizi seimbang pada masa pandemi covid. 
Peraturan Pemerintah No. 4 tahun 2014 tentang Penyelenggaraan Pendidikan Tinggi dan Pengelolaan Perguruan Tinggi.

Peraturan Menteri Kesehatan Republik Indonesia nomor 41 tahun 2014 tentang Pedoman gizi seimbang. 